\title{
Community Resources as the Indigenous Tourism Product of the Mah Meri People in Malaysia
}

\author{
Puvaneswaran Kunasekaran ${ }^{1}$, Sarjit Singh Gill ${ }^{1} \&$ Ahmad Tarmizi Talib ${ }^{1}$ \\ ${ }^{1}$ Faculty of Human Ecology, University Putra Malaysia, Malaysia \\ Correspondence: Sarjit Singh Gill, Faculty of Human Ecology, University Putra Malaysia, 43400 Selangor, \\ Malaysia. Tel: 60-3-8946-7059. E-mail: sarjit@putra.upm.edu.my
}

\author{
Received: March 19, 2015 Accepted: April 3, 2015 Online Published: July 29, 2015 \\ doi:10.5539/jsd.v8n6p158 URL: http://dx.doi.org/10.5539/jsd.v8n6p158
}

\begin{abstract}
This paper presents the significant role of resources which is utilized by the Mah Meri community in Pulau Carey, Malaysia to practice sustainable tourism. Preliminary study was conducted at Kampung Sungai Bumbon which is a well-established indigenous tourism destination in Malaysia. In-depth interview which was used as the qualitative data collection method helped the researchers to holistically understand the community resources which can encourage sustainable tourism practice. Natural tourism products like wood carvings and weavings are the main attributes which contribute to tourism development. This study reveals that the community is proud of its diversified environment. However, the community feels that their culture and tourism gradually facing great threat because of the scarcity of natural resources. It is hoped that the findings of this study will contribute to existing literature in the indigenous tourism and community resources ground.
\end{abstract}

Keywords: ecotourism, indigenous people, sustainability, scarcity

\section{Introduction}

Orang Asli or "original people" is used to refer to the indigenous peoples in Peninsular Malaysia. The term Orang Asli is a substitute of the term 'aborigines' used by the British colonial administration (Gomes, 2004). This minority community with overall population of only 178,197 represents $0.5 \%$ of the Malaysian population. In 2010, JAKOA (Indigenous People Development Department) reported that Orang Asli population had increased to 178,197 in 2010 compared to only 141,230 in 2006. Categorized as minority groups in the country, they comprise of three main groups, namely, Negrito, Senoi/Semai and Proto-Malay.

Orang Asli were separated into three nationwide categories during the English colonization for the objective of assisting the management in those days (July Edo, 2006). Each group was separated into sectors; groups situated in several locations in the woodlands, the hills, the rural areas and near the coastline or stream estuary (Amran Kasimin, 1995).

Gomes (2004) stressed that there should be no doubt that the predecessors of the Orang Asli settled in the Malay Peninsula earlier than the predecessors of Malay community. Hasan Mat Nor (1998) in his work argued that the Negritos are considered to have come to the Malay Peninsula about 25,000 years ago. However, the Semai are the largest population and the oldest indigenous community in Peninsular Malaysia (Ying, 2009). Most of the Semai live at the foothill and mountain areas in the borders of Perak and Pahang (Dentan, 2000). The headman of the Orang Asli community is generally known as 'Tok Batin'. The Tok Batin is in charge of internal affairs and issues regarding the group. Apart from that, the Tok Batin also is responsible for maintaining the inherited customs, traditions and order in the village.

The Mah Meri community is one of the sub-ethnic groups of the major Senoi group. Mah Meri community consists of 2896 members in the year 2004 (JHEOA, 2004). They speak an Austroasiatic language which is originally from the Mon and Khmer's language family. However, they Mah Meri's route to reach Malay Peninsula is still not clear and mainly rely on myths (Nowak, 1987) and (Suet, 2010).

One of the earliest notes of Carey Island was recorded by Nowak (1987) saying that during the 1900s about 20,000 acres out of 35,000 acres of the mangrove and rainforest were converted into commercial oil palm plantations. This big scale transformation has caused destruction in basic resources, extinction of flora and fauna and disruption of natural ecosystem. Areas which used to be accessed for fishing, hunting and recreation are not 
accessible result in the change of ecological system which reflects in the musical, material and cultural contents of the Mah Meri's performances (Suet, 2010).

According to Nicholas (2000), the modernization is intended to improve the Orang Asli villages in the country in terms of education, health, electricity and water. Suet (2010) stressed that the destruction of the ancestral territories, natural resources, forest and river accessibility have hugely disappointed the Mah Meri community. This has made the community to realize that they still have their arts and performing traditions well-kept to strengthen their value in the country and make the government appreciate them. This can be seen in various touristic products of the community; weavings, woodcarvings, masks, Main Jo'oh dance marketed in Tourism Malaysia website, internet websites, tourists guide books, and magazines (Kunasekaran, 2013).

Thus, it can be said that the community has chosen tourism as a tool to portray their uniqueness to outsiders and enjoy some financial advantages at the same time. Sarkissian (1988) who studied the tradition and the cultural shows to be displayed for tourism purpose however argue the tourism products are only at the level of staged performances and not to create any cultural awareness.

\section{Method}

The data was collected from Kampung Sungai Bumbon, Carey Island. Snowballing (Cooper and Schindler, 1998) and theoretical sampling (Minichiello, 1991) are the combined selection procedures that will be used to carry out this research. The semi-structured interview was used as an inductive approach to gain new and unexpected responses from the respondents, which prevents the interviewer from assuming potential variables. However, a questionnaire guide was developed and used throughout the interviewing session to obtain the pattern of answers that are appropriate to the objectives of the study. The naturalistic inquiry technique will provide a set of data which is not biased where the real problem in the community can be understood (Kvale, 1997). The data from the naturalistic inquiry was analyzed using a discourse analysis technique.

\section{Results}

The results from the in depth interviews revealed that the community heavily depend on the resources around them. Natural resources are found to be the most significant form of materials that the need to operate tourism business and activities. Apart from that, the possession of indigenous knowledge from ancestors is also important in order to polish their unique culture.

Generally the community relies heavily on its surroundings to produce their handicraft. For the mask and sculpture, reddish hardwood called Nyireh Batu (Xylocarpus Moluccensis) is often used.

"In the wood carving process, first we got to go looking for the raw material to carve, if the wood is suitable to carve, we go ahead. We created this mask using Nyireh Batu, there is a scientific name for it - I did not know how to say it - instead of mangrove wood. We must bring Genso (chainsaw) machine, cut wood, stack it behind the house, measure how many feet that we need... If anyone gets an order,then the size will be according to the price and if the price is high, we have to do a big one. If the price is low we make a small one. If the price is low, it will be about five hundred Ringgit. When the big order comes, I think it is about four thousand, five thousand. Now we can't make big objects because the wood is slowly dying out...I mean Nyireh Batu, we can't find big wood. The mangrove marsh is also disappearing" (Atan Seman, 47 years old, male)

Some of the wood carvers said that the orders to make mask and sculptures are not encouraging. This inconsistency of demand has caused them to be involved in other activities in the village.

"For instance, I don't get orders like others, I have to be like this, I still do wood carving, do and keep. Even though no order, I still do and keep stock. Another thing is, at my house there are no more masks, we have to do mask, so that when there is an order, we can easily sell. We cannot wait for the order, if you wait for the order; it can be a problem too." (Kemi, 38 years old, male)

Dissimilarly, for the weaving activity, resource scarcity is not a major issue. The Pandanus leaf can be found easily. However, it is reducing in the vicinity of the village and weavers have to venture farther from the village to gather the leaf.

"No...Not like the Nyireh Batu, Nyireh Batu is slowly diminishing...Look there...that durian tree is mine...I planted so that one day it will grow and provide me with the wood which is similar to the Nyireh Batu. Do you know that the durian tree wood is a hardwood? For now I am happy that there is a lot of Pandanus leaf out there. Even around my house, you can find many. But is it is slowly disappearing from this area. We have to go far to get some." (Maznah anak Unyan, 44 years old, female)

According to another wood carver, the scarcity of Nyireh Batu is caused by the commercial development of an oil palm plantation owned by a multinational company.

"We have to plant this wood in a place...We don't want them to destroy more...we have to keep more wood... 
because this hardwood is difficult to get... Just like us (Mah Meri), the wood is diminishing, but a lot of anak nyireh (young Nyireh), ibu nyireh (matured Nyireh) can be found near the mangrove marsh, kind of easy resource I guess... The hardwood is diminishing because there are no more rivers...the river was wider than what it is now, because of this problem we want to save forests but could not because they want the land for planting oil palm. Now I heard they want to cut again. For us, we already told Sime Darby about the trees used for carving...if we take the anak nyireh we must ask permission from Sime Darby. For us it is hard to think that every time we enter to get wood, we must seek permission, those days we were not like this." (Alias Sayor, 35 years old, male)

The community is arguably rich with indigenous knowledge. According to the key informants there is no need for formal education to the next generation as they are practicing the culture every day.

"My mother never taught me this weaving earlier...I just learnt it myself...I would follow her to collect the Pandan leaf and just follow whatever she does. I just do whatever my sister does. Nobody taught me...I can just do this from morning until night...Playing Genang, I learnt it earlier and it is easy now." (Pinta anak Unyan, 35 years old, female)

Another respondent said that his father has taught him the wood carving skills. Apart from that, he frequently visits other wood carvers' houses to learn the techniques.

"When I was 12 years old, I started to carve a statue, since then my interest increased. I am learning until now. Many are teaching, not only my father is teaching, I sometimes go to the homes of other men to see how they make the statue. My father has a book which has got all the designs of Mah Meri sculptures. I always refer to the book. Sometimes the idea is from me, this idea is from me (while pointing to a statue of a dragon in his hands)." (Razzie anak Gali, 18 years old, male)

Another respondent who is the son of the Tok Batin said that for him the wood carving is not a main source of income because he was involved in oil palm work.

"I was involved in carving indirectly. Actually I got involved in this thing because it is important to study for inheritance. We need to know the principles of the carvings. I don't know weaving much but it is compulsory to know the basics. It is a shame if we do not know. I followed good carvers for five years I have participated officially in the learning process. During schooling, carving was for fun and hobby but after schooling; it is a more of a job" (Yahya Sidin, 33 years old, male)

The outcome of the conversations clearly shows that the community is not utilizing the resources because inconsistent of the demand and scarcity of resources. However, economic benefit is not their main reason for cultural commodification (Kunasekaran, 2011). Cultural tourism mainly emphasized to preserve the uniqueness and belief of the community.

\section{Conclusion}

The investigation shows that the indigenous community is proud to portray their uniqueness to the outsiders. They are also proud to be known as the icon of tourism among other Orang Asli sub-groups of Malaysia. This study also reveals that the Mah Meri community is eager to explore the resources in their village. They strongly believe that the tourism business can create many positive outcomes. Apart from that, the community also agrees that the non-economic benefits such as cultural sustainability and environmental sustainability are driven by the emergence of tourism in their village. One of the crucial threats felt by almost all the villagers is the diminishing supply of the Niyireh Batu. The community fears that wood carving could be hugely affected if the situation continues. The Forestry Department must play a vital role in replanting the trees without any delay to ensure that the community can still do wood carving in future. Apart from that, the government can also assist the villagers by providing the monthly lorry transportation to go as far as Banting to collect the resource. According to the community, although the wood cannot be found in Carey Island, it can be found near Banting (nearest town). They could not go very far to collect the wood because of financial and transportation problem.

\section{Acknowledgments}

This research is funded by Ministry of Higher Education, Malaysia under the Fundamental Research Grant Scheme.

\section{References}

Amran, K. (1995). Agama dan Perubahan Sosial di Kalangan Penduduk Asli di Semenanjung Tanah Melayu. Kuala Lumpur: Dewan Bahasa dan Pustaka.

Asnarulkhadi, A. S. (2003). Pengenalan Pembangunan Komuniti. Serdang: Selaseh Press Sdn.Bhd.

Cooper, D. R., \& Schindler, P. S. (1998). Business Research Methods. Singapore: McGraw-Hill.

Dentan, R. K. (2000). The Semai of Malaysia. In L. E. Sponsel (Ed.), Endangered Peoples of Southeast \& East Asia: Struggles To Survive and Thrive (pp. 209-232). Westport, CT: Greenwood Publishing Group. 
Dentan, R. K., Endicott, K., Gomes, A. G., \& Hooker, M. B. (1997). Malaysia and the Original People: A Case Study of the Impact of Development on Indigenous Peoples. Massachusetts: Allyn and Bacon.

Flora, C. B. (2008). Rural Communities: Legacy and Change (3rd ed.). Boulder, CO: Westview Press.

Frank, F., \& Smith, A. (1999). The community development handbook: A tool to build community capacity. Ottawa, ON: Human Resources Development Canada.

Gomes, A. G. (2004). The Orang Asli of Malaysia. International Institute for Asian Studies Newsletter, 35, 10.

Hasan, M. N. (1998). Warga Pribumi Menghadapi Cabaran Pembangunan, Kertas Kadangkala Bil. 8. Bangi: Universiti Kebangsaan Malaysia.

Hunter, C. (1997). Sustainable tourism as an adaptive paradigm. Annals of tourism research, 24(4), 850-867. http://dx.doi.org/10.1016/S0160-7383(97)00036-4

Jabatan Hal-Ehwal Orang Asli (JHEOA). (2004). Data Maklumat Asas Jabatan Hal Ehwal Orang Asli Malaysia. Kuala Lumpur: Bahagian Penyelidikan dan Perancangan.

Jithendran, K. J., \& Baum, T. (2000). Human resources development and sustainability - the case of Indian tourism. International Journal of Tourism Research, 2(6), 403-421. http://dx.doi.org/10.1002/1522-1970(200011/12)2:6<403::AID-JTR239>3.0.CO;2-3

Juli, E. (2006). Retorik Pembangunan Orang Asli. Dalam Malaysia Menangani Perubahan dan Pembangunan, 187-229. Kuala Lumpur: Universiti Malaya Press.

Kunasekaran, P., Gill, S. S., Talib, A. T., \& Redzuan, M. R. (2013). Culture As An Indigenous Tourism Product Of Mah Meri Community In Malaysia. Life Science Journal, 10(3).

Kunasekaran, P., Ramachandran, S., Samdin, Z., \& Awang, K. (2012). Factors Affecting Farmers’ Agro Tourism Involvement in Cameron Highlands, Pahang. OIDA International Journal of Sustainable Development, 4(1), 83-90.

Kunasekaran, P., Ramachandran, S., Yacob, M. R., \& Shuib, A. (2011). Development of farmers' perception scale on agro tourism in Cameron Highlands, Malaysia. World Applied Sciences Journal, 12(Special Issue of Tourism \& Hospitality), 10-18.

Kvale, S. (1996). Inter Views: An Introduction to Qualitative Research Interviewing. Thousand Oaks, California: Sage.

Minichiello, V., Aroni, R., Timewell, E., \& Alexander, L. (1991). In-depth Interviewing; Researching People. Cheshire, Melbourne: Longman.

Nicholas, C. (2000). The Orang Asli and the Contest for Resources: Indigenous Politics, Development and Identity in Peninsular Malaysia. Copenhagen: IWGIA and Subang Jaya: COAC.

Nowak, S. (1987). Marriage and Household: Btsisi' Response to a Changing World. PhD dissertation, State University of New York at Buffalo.

Pearce, D. W., Markandya, A., \& Barbier, E. B. (1989). Blueprint for a green economy. Earthscan/James \& James.

Pearce, P. L. (1995). From culture shock and culture arrogance to culture exchange: Ideas towards sustainable socio-cultural tourism. Journal of Sustainable Tourism, 3(3), 143-154.

Sarkissian, M. (1998). Tradition, Tourism, and the Cultural show: Malaysia's Diversity on Display. Journal of Musicological Research, 17(2), 87-113. http://dx.doi.org/10.1080/01411899808574742

Sharp, J. S., Agnitsch, K., Ryan, V., \& Flora, J. (2002). Social infrastructure and community economic development strategies: the case of self-development and industrial recruitment in rural Iowa. Journal of Rural Studies, 18(4), 405-417. http://dx.doi.org/10.1016/S0743-0167(02)00011-6

Suet, C. C. (2010). Mah Meri on Stage: Negotiating National Policies, Tourism and Modernization in Kampung Sungai Bumbun, Carey Island. PhD theses. University of Hawai.

Vidal, A. C. (1997). Can Community Development Re-Invent Itself? The Challenges of Strengthening Neighborhoods in the 21st Century. Journal of the American Planning Association, 63(4), 429-438.

Voora, V., \& Venema, H. D. (2008). An ecosystem services assessment of the Lake Winnipeg watershed. Phase 1 report-Southern Manitoba.

Ying, L. Y. (2009). Empowering the Semai People Through Participation in Community Development Programmes. Unpublished Master dissertation. University Putra Malaysia, Serdang.

\section{Copyrights}

Copyright for this article is retained by the author(s), with first publication rights granted to the journal.

This is an open-access article distributed under the terms and conditions of the Creative Commons Attribution license (http://creativecommons.org/licenses/by/3.0/). 